\title{
Micromonospora marina sp. nov., isolated from sea sand
}

\author{
Somboon Tanasupawat, ${ }^{1}$ Suchada Jongrungruangchok ${ }^{1}$ and Takuji Kudo ${ }^{2}$ \\ ${ }^{1}$ Department of Microbiology, Faculty of Pharmaceutical Sciences, Chulalongkorn University, \\ Bangkok 10330, Thailand \\ 2Japan Collection of Microorganisms, RIKEN BioResource Center, Wako, Saitama 351-0198, \\ Japan
}

Correspondence

Somboon Tanasupawat

Somboon.T@chula.ac.th

\begin{abstract}
Two actinomycete strains, JSM $1-1^{\top}$ and JSM1-3, were isolated from sea sand collected in Thailand. Their taxonomic position was determined using a polyphasic approach. The chemotaxonomic characteristics of these strains coincided with those of the genus Micromonospora, i.e. the presence of meso-diaminopimelic acid and $N$-glycolyl muramic acid in the peptidoglycan, whole cell sugar pattern D, phospholipids type II, and cellular fatty acid type $3 \mathrm{~b}$. Phylogenetic analysis of $16 \mathrm{~S}$ rRNA gene sequences revealed a close relationship between strains $\mathrm{JSM} 1-1^{\top}$ and JSM1-3 (99.8\%), and between JSM1-1 ${ }^{\top}$ and Micromonospora aurantiaca JCM $10878^{\top}$ (99.3\%), Micromonospora chalcea JCM $3031^{\top}$ (99.0\%), and Micromonospora coxensis JCM $13248^{\top}$ (99.0\%). However, strains JSM1-1 ${ }^{\top}$ and JSM1-3 could be clearly distinguished from these type strains by a low DNA-DNA relatedness and by phenotypic differences. On the basis of the data presented, a new species, Micromonospora marina sp. nov., is proposed. The type strain is JSM $1-1^{\top}(=\mathrm{JCM}$ $12870^{\top}=\operatorname{PCU} 269^{\top}=$ TISTR $1566^{\top}$ ).
\end{abstract}

The actinomycete genus Micromonospora was proposed by Ørskov (1923) on the basis of morphological properties, which include the absence of a true aerial mycelium and the presence of spores borne singly on the substrate mycelium. Strains belonging to the genus Micromonospora are distributed widely in different environments, such as soils, water, sandstone and root nodules (Hirsch et al., 2004; Kawamoto, 1989; Trujillo et al., 2005, 2006; Ara \& Kudo, 2007). The genus Micromonospora was redefined to 14 species by Kasai et al. (2000) based on gyrB and 16S rRNA gene sequence analyses and DNA-DNA relatedness. More recently, the species Micromonospora auratinigra, M. eburnea, M. endolithica, $M$. mirobrigensis, $M$. siamensis, $M$. citrea, $M$. echinaurantiaca, M. echinofusca, $M$. fulviviridis, M. inyonensis, M. peucetia, M. sagamiensis, $M$. viridifaciens, M. coriariae, M. chokoriensis, M. coxensis, M. lupini, M. saelicesensis, M. chaiyaphumensis, M. krabiensis and M. narathiwatensis were reported (Hirsch et al., 2004; Trujillo et al., 2005, 2006,

The GenBank/EMBL/DDBJ accession number for the $16 \mathrm{~S}$ rRNA gene sequence of strains $\mathrm{JSM} 1-1^{\top}$ and $\mathrm{JSM} 1-3$ are $\mathrm{AB} 196712$ and AB196713, respectively.

A scanning electron micrograph of strain JSM1-1T, a maximumparsimony tree based on 16S rRNA gene sequences and tables containing cultural characteristics, cellular fatty acid profiles, and DNA $\mathrm{G}+\mathrm{C}$ content and DNA-DNA relatedness of strains JSM1-1T and JSM1-3 are available with the online version of this paper.
2007; Thawai et al., 2004, 2005a, b, 2008; Kroppenstedt et al., 2005; Ara \& Kudo, 2007; Jongrungruangchok et al., $2008 \mathrm{a}, \mathrm{b})$.

During the course of an investigation of rare actinomycetes from sea sand in Thailand, we isolated two actinomycetes, JSM1-1 ${ }^{\mathrm{T}}$ and JSM1-3, which showed the typical morphological characteristics of the genus Micromonospora. In this paper we report the taxonomic characterization and classification of these isolates and propose that they represent a new species, Micromonospora marina sp. nov.

Strains JSM1-1 ${ }^{\mathrm{T}}$ and JSM1-3 were isolated from sand collected along the sea shore in Hua-Hin, Prajuabkirikhun province, Thailand, by using starch-casein nitrate agar [10 g starch, $0.3 \mathrm{~g}$ sodium caseinate (Difco), $2 \mathrm{~g} \mathrm{KNO}_{3}$ and $15 \mathrm{~g}$ agar per litre; $\mathrm{pH} 7.0-7.4]$ incubated at $30{ }^{\circ} \mathrm{C}$ for 21 days. They were purified and maintained on yeast extract-malt extract agar, ISP 2 (The International Streptomyces Project medium 2), as described by Shirling \& Gottlieb (1966). The isolates were grown on ISP 2 agar and oatmeal agar, ISP 3 (Shirling \& Gottlieb, 1966), for 2 weeks at $30{ }^{\circ} \mathrm{C}$ and were observed by light and scanning electron microscopy (model JSM-5410 LV; JEOL). Samples for scanning electron microscopy were prepared as described previously (Itoh et al., 1989). The HuckerConn method was used for the Gram stain (Hucker \& Conn, 1923). 
Cultural characteristics were determined by using 14-dayold cultures grown at $30{ }^{\circ} \mathrm{C}$ on ISP media, as described by Shirling \& Gottlieb (1966). The Colour Harmony Manual (Jacobson et al., 1958) was used for determining colours of colonies. Gelatin liquefaction, milk peptonization, nitrate reduction and starch hydrolysis were determined as described by Arai (1975) and Williams \& Cross (1971). The decomposition of various compounds was examined by using the basal media recommended by Gordon et al. (1974). The utilization of carbohydrates as sole carbon sources was tested by using neutralized yeast nitrogen base without amino acids (Difco) as a basal medium, supplemented with $1 \%(\mathrm{w} / \mathrm{v})$ carbon sources and $0.05 \%(\mathrm{w} / \mathrm{v})$ amino acids according to the method of Stevenson (1967). Tolerance to sodium chloride and the effect of temperature and $\mathrm{pH}$ on growth were determined on Sucrose Bennett's Agar (Arai, 1975). In addition, tyrosine agar (ISP 7) and peptone-iron agar (ISP 6) supplemented with $0.1 \%(\mathrm{w} / \mathrm{v})$ yeast extract were used to determine melanoid pigment production.

Freeze-dried cells required for chemotaxonomic analyses were obtained from cultures grown in ISP 2 broth incubated on a rotary shaker at $30{ }^{\circ} \mathrm{C}$ for 14 days. Cell wall peptidoglycan was prepared and hydrolysed as described by Kawamoto et al. (1981). The isomers of diaminopimelic acid in the cell walls were determined as described by Staneck \& Roberts (1974). Reducing sugars from whole cell hydrolysates were analysed by the HPLC method of Mikami \& Ishida (1983). The acyl group of muramic acid in the peptidoglycan was determined using the method of Uchida \& Aida (1984). Phospholipids in cells were extracted and identified as described by Minnikin et al. (1984). Methyl esters of cellular fatty acids were prepared by the direct transmethylation method with methanolic hydrochloride (Suzuki \& Komagata, 1983) and were analysed by using GLC according to the instructions of the Microbial Identification System (MIDI) (Sasser, 1990; Kämpfer \& Kroppenstedt, 1996) as described previously (Kudo et al., 1993). The identification of each peak was carried out by comparison with commercially available standards and by using GC-MS. Isoprenoid quinones were extracted by the method of Collins et al. (1977) and were analysed by HPLC with a Cosmosil $5 \mathrm{C}_{18}$ column ( 4.6 by $150 \mathrm{~mm}$; Nacalai Tesque). Methanol/2propanol $(2: 1, \mathrm{v} / \mathrm{v})$ was used as an eluent.

DNA was extracted from cells grown in ISP 2 broth according to the method of Tamaoka (1994). The G + C content of the DNA was determined using HPLC as described by Tamaoka \& Komagata (1984). DNA-DNA relatedness was carried out in $2 \times$ SSC (saline trisodium citrate) and $50 \%$ formamide solution at $53{ }^{\circ} \mathrm{C}$ for $5 \mathrm{~h}$ (Ezaki et al., 1989). Genomic DNA extraction, PCRmediated amplification of the $16 \mathrm{~S}$ rRNA genes, and sequencing of the PCR products were carried out as described by Nakajima et al. (1999). The sequences of the two strains were multiply aligned with selected sequences obtained from the GenBank/EMBL/DDBJ databases by using the CLUSTAL_X program (Thompson et al., 1997). The phylogenetic trees were reconstructed using the Kimura two-parameter model in the neighbour-joining method (Saitou \& Nei, 1987) and the maximum-parsimony method using MEGA version 3.1 (Kumar et al., 2004). The confidence values of branches of the phylogenetic trees were determined using bootstrap analyses (Felsenstein, 1985 ) based on 1000 resamplings. Gaps and ambiguous nucleotides were eliminated from the calculations.

Strains JSM1-1 ${ }^{\mathrm{T}}$ and JSM1-3 had morphological, cultural and chemotaxonomic properties consistent with their classification in the genus Micromonospora. They formed well-developed and branched substrate hyphae. No aerial mycelium was produced. Spores at maturity were spherical to oval, appeared to be smooth and were non-motile (Supplementary Fig. S1, available in IJSEM Online). The phenotypic characteristics of strains JSM $1-1^{\mathrm{T}}$ and JSM1-3 are presented in the species description and in Table 1 and Supplementary Tables S1 and S2. The strains contained meso-diaminopimelic acid in the cell wall. The acyl type of the cell wall in the peptidoglycan was determined to be the glycolyl type. Whole-cell sugars were detected as glucose, xylose, mannose, ribose, galactose and arabinose [pattern D of Lechevalier \& Lechevalier (1970)]. The polar lipid profile contained diphosphatidylglycerol, phosphatidylinositol, phosphatidylinositol mannosides and phosphatidylethanolamine [type PII pattern of Lechevalier et al. (1977)]. Significant fatty acids of strains JSM1-1 ${ }^{\mathrm{T}}$ and JSM1-3 were iso- $\mathrm{C}_{15: 0}(20.1-25.1 \%)$, iso- $\mathrm{C}_{16: 0}(16.4-21.6 \%)$, iso- $\mathrm{C}_{17: 0}$ $(5.4-7.9 \%)$, anteiso- $\mathrm{C}_{17: 0}(6.9-7.7 \%)$, iso- $\mathrm{C}_{17: 1} \omega 9 c(6.4-$ $6.9 \%)$ and 10-methyl $\mathrm{C}_{17: 0}(1.2-5.7 \%)$ (Supplementary Table S2). This pattern corresponded to fatty acid type $3 \mathrm{~b}$ of Kroppenstedt (1985). The predominant menaquinones were $\mathrm{MK}-10\left(\mathrm{H}_{4}\right) \quad(52.0-55.0 \%), \quad \mathrm{MK}-10\left(\mathrm{H}_{6}\right) \quad$ (18.3$22.2 \%)$, MK-10 $\left(\mathrm{H}_{8}\right) \quad$ (3.7-6.1\%), MK-10 $\left(\mathrm{H}_{2}\right) \quad$ (2.5$2.8 \%)$, MK-9 $\left(\mathrm{H}_{4}\right) \quad(5.9-6.0 \%)$ and MK-9 $\left(\mathrm{H}_{6}\right)$ (2.1$2.3 \%)$. Trace amounts of MK-9 $\left(\mathrm{H}_{2}\right)$ and MK-10 $\left(\mathrm{H}_{0}\right)$ were

Table 1. Differential characteristics of strains $J S M 1-1^{\top}$ and JSM1-3 and related species of the genus Micromonospora

Strains: 1, JSM1-1 ${ }^{\mathrm{T}}$; 2, JSM1-3; 3, M. aurantiaca JCM $10878^{\mathrm{T}} ;$ 4, M. chalcea JCM $3031^{\mathrm{T}}$. +, Positive; w, weakly positive; -, negative.

\begin{tabular}{|c|c|c|c|c|}
\hline Characteristic & 1 & 2 & 3 & 4 \\
\hline Decomposition of tyrosine & + & + & + & - \\
\hline Growth at $\mathrm{pH} 5$ & + & + & + & - \\
\hline Maximum $\mathrm{NaCl}$ tolerance $(\%)$ & 7 & 7 & 4 & 5 \\
\hline \multicolumn{5}{|l|}{ Utilization of: } \\
\hline L-Arabinose & + & $\mathrm{W}$ & + & $\mathrm{W}$ \\
\hline Glycerol & $\mathrm{w}$ & $\mathrm{w}$ & - & - \\
\hline Lactose & - & - & + & + \\
\hline D-Mannitol & $\mathrm{W}$ & $\mathrm{W}$ & - & - \\
\hline Raffinose & + & + & $\mathrm{w}$ & + \\
\hline D-Ribose & + & + & - & - \\
\hline
\end{tabular}


also detected. The DNA G $+\mathrm{C}$ contents of JSM1-1 ${ }^{\mathrm{T}}$ and JSM1-3 were 72.0 and $71.9 \mathrm{~mol} \%$, respectively.

Analysis of the almost complete 16S rRNA gene sequences (1436 nt) of strains JSM1- $1^{\mathrm{T}}$ and JSM1-3 indicated that they were $99.8 \%$ related to each other and that they formed a monophyletic clade with the closely related species Micromonospora aurantiaca JCM $10878^{\mathrm{T}}(99.3 \%)$, Micromonospora chalcea JCM $3031^{\mathrm{T}}(99.0 \%)$, Micromonospora coxensis JCM $13248^{\mathrm{T}}(99.0 \%)$, Micromonospora halophytica DSM $43171^{\mathrm{T}}(98.8 \%)$ and Micromonospora purpureochromogenes DSM $43821^{\mathrm{T}}(98.8 \%)$, as shown in Fig. 1 and Supplementary Fig. S2 (tree reconstructed by the maximum-parsimony method). Comparison with the descriptions of previously characterized species of the genus Micromonospora showed that our novel isolates were distinguishable from the related species M. aurantiaca JCM $10878^{\mathrm{T}}$ and M. chalcea JCM $3031^{\mathrm{T}}$ by a combination of biochemical and physiological properties, in particular decomposition of tyrosine, utilization of Larabinose, glycerol (weak), lactose, D-mannitol, raffinose and D-ribose, growth at $\mathrm{pH} 5$ and maximum $\mathrm{NaCl}$ tolerance $(7 \%)$ (Table 1$)$.

The level of DNA-DNA relatedness between strains JSM1$1^{\mathrm{T}}$ and JSM1-3 was 92-97\%, while the levels of DNA-DNA relatedness between these strains and the type strains of closely related species $M$. aurantiaca JCM $10878^{\mathrm{T}}$, M. chalcea JCM $3031^{\mathrm{T}}$ and M. coxensis JCM $13248^{\mathrm{T}}$ were less than $44-49 \%$ (Supplementary Table S3). These values were obtained from independent determinations and are below the threshold value of $70 \%$ for distinguishing genomic

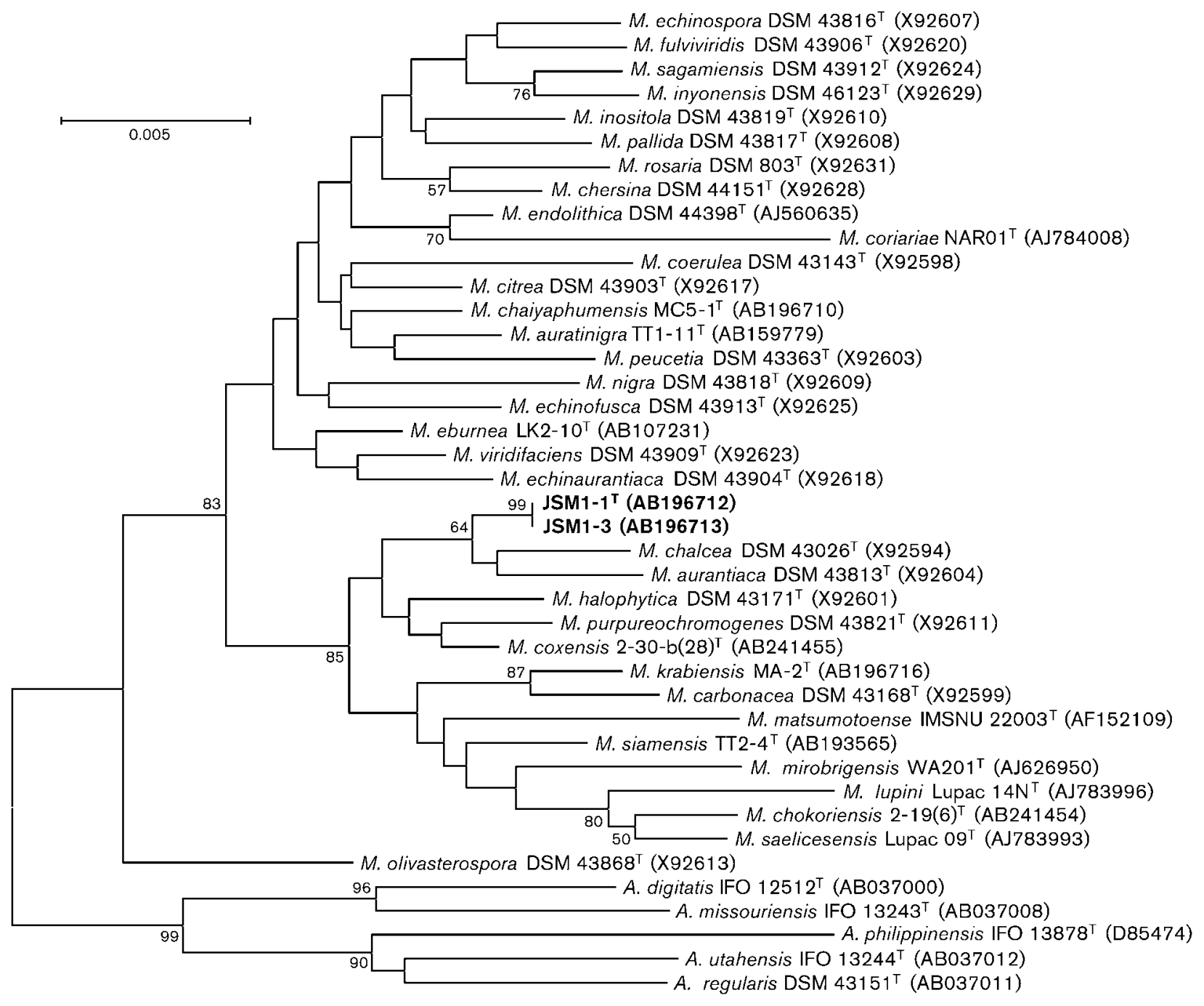

Fig. 1. Neighbour-joining tree based on almost complete 16S rRNA gene sequences showing the phylogenetic relationships between strains JSM1-1 and JSM1-3, all type strains of the genus Micromonospora, and related species of the genus Actinoplanes. Based on 1000 replications, bootstrap percentages above $50 \%$ are shown. Bar, 0.005 substitutions per nucleotide position. 
species (Wayne et al., 1987). It is evident from the genotypic and phenotypic data that strains JSM1-1 ${ }^{\mathrm{T}}$ and JSM1-3 form a new taxonomic position in the genus Micromonospora. Consequently, we propose a novel species, Micromonospora marina sp. nov., to accommodate strains JSM1-1 ${ }^{\mathrm{T}}$ and JSM1-3.

\section{Description of Micromonospora marina sp. nov.}

Micromonospora marina sp. nov. (ma. ri' na. L. fem. adj. marina of the sea, marine, pertaining to sea sand, the source from which the type strain was isolated).

Aerobic, Gram-positive, mesophilic actinomycete that forms a well-developed and extensively branched substrate mycelium. No aerial mycelium is produced. The vegetative mycelium on ISP 2 is brownish orange, turning to brownish black upon sporulation. A pale yellow diffusible pigment is produced on ISP 2 and a pale brown to brown pigment on ISP 7. Spores are spherical to oval, appear to be smooth and are non-motile. Nitrate reduction is negative. Starch hydrolysis, gelatin liquefaction and milk peptonization are positive. Decomposes L-tyrosine, but not adenine, hypoxanthine or xanthine. Utilizes L-arabinose, D-fructose, D-galactose, D-glucose, glycerol (weakly), D-mannitol (weakly), melibiose, raffinose, D-ribose and D-xylose, but not lactose, L-rhamnose or salicin as sole carbon sources for energy. The optimal temperature for growth is 25$30{ }^{\circ} \mathrm{C}$. Grows at $15-45{ }^{\circ} \mathrm{C}$, at $\mathrm{pH} 5$ to 9 , and in the presence of $7 \% \mathrm{NaCl}$. The cell wall peptidoglycan contains glutamic acid, alanine and meso-diaminopimelic acid. The acyl type of the cell wall is glycolyl. The predominant menaquinones are MK-10 $\left(\mathrm{H}_{4}\right)$ and $\mathrm{MK}-10\left(\mathrm{H}_{6}\right)$. Major cellular fatty acids are iso- $\mathrm{C}_{15: 0}$ and iso- $\mathrm{C}_{16: 0}$. The DNA $\mathrm{G}+\mathrm{C}$ content of the type strain is $72.0 \mathrm{~mol} \%$. Habitat is sea sand.

The type strain is JSM1-1 ${ }^{\mathrm{T}}\left(=\mathrm{JCM} 12870^{\mathrm{T}}=\mathrm{PCU} 269^{\mathrm{T}}\right.$ $=$ TISTR $1566^{\mathrm{T}}$ ), isolated from sea sand in Thailand.

\section{Acknowledgements}

This study was supported by the Thailand Research Fund for a 2002 Royal Golden Jubilee PhD Program as a scholarship to S. J. We thank Miss Jiraporn Chantongcome for collecting sea sand samples and isolation of the strains.

\section{References}

Ara, I. \& Kudo, T. (2007). Two new species of the genus Micromonospora: Micromonospora chokoriensis sp. nov. and Micromonospora coxensis sp. nov., isolated from sandy soil. J Gen Appl Microbiol 53, 29-37.

Arai, T. (1975). Culture Media for Actinomycetes. Tokyo: The Society for Actinomycetes Japan.

Collins, M. D., Pirouz, T., Goodfellow, M. \& Minnikin, D. E. (1977) Distribution of menaquinones in actinomycetes and corynebacteria. J Gen Microbiol 100, 221-230.

Ezaki, T., Hashimoto, Y. \& Yabuuchi, E. (1989). Fluorometric deoxyribonucleic acid-deoxyribonucleic acid hybridization in micro- dilution wells as an alternative to membrane filter hybridization in which radioisotopes are used to determine genetic relatedness among bacterial strains. Int J Syst Bacteriol 39, 224-229.

Felsenstein, J. (1985). Confidence limits on phylogenies: an approach using the bootstrap. Evolution 39, 783-791.

Gordon, R. E., Barnett, D. A., Handerhan, J. E. \& Pang, C. H.-N. (1974). Nocardia coeliaca, Nocardia autotrophica, and the nocardin strain. Int J Syst Bacteriol 24, 54-63.

Hirsch, P., Mevs, U., Kroppenstedt, R. M., Schumann, P. \& Stackebrandt, E. (2004). Cryptoendolithic actinomycetes from Antarctic sandstone rock samples: Micromonospora endolithica sp. nov. and two isolates related to Micromonospora coerulea Jensen 1932. Syst Appl Microbiol 27, 166-174.

Hucker, G. J. \& Conn, H. J. (1923). Method of Gram staining N Y State Agric Exp Stn Tech Bull 93, 3-37.

Itoh, T., Kudo, T., Parenti, F. \& Seino, A. (1989). Amended description of the genus Kineosporia, based on chemotaxonomic and morphological studies. Int J Syst Bacteriol 39, 168-173.

Jacobson, E., Grauville, W. C. \& Fogs, C. E. (1958). Color Harmony Mannual, 4th edn. Chicago: Container Corporation of America.

Jongrungruangchok, S., Tanasupawat, S. \& Kudo, T. (2008a). Micromonospora chaiyaphumensis sp. nov., isolated from Thai soils. Int J Syst Evol Microbiol 58, 924-928.

Jongrungruangchok, S., Tanasupawat, S. \& Kudo, T. (2008b). Micromonospora krabiensis sp. nov., isolated from marine soil in Thailand. J Gen Appl Microbiol 54, 127-133.

Kämpfer, P. \& Kroppenstedt, R. M. (1996). Numerical analysis of fatty acid patterns of coryneform bacteria and related taxa. Can J Microbiol 42, 989-1005.

Kasai, H., Tamura, T. \& Harayama, S. (2000). Intrageneric relationships among Micromonospora species deduced from gyrB-based phylogeny and DNA relatedness. Int J Syst Bacteriol 50, 127-134.

Kawamoto, I. (1989). Genus Micromonospora Ørskov 1923, $147^{\mathrm{AL}}$. In Bergey's Manual of Systematic Bacteriology, vol. 4, pp. 2442-2450. Edited by S. T. Williams, M. E. Sharpe \& J. G. Holt. Baltimore: Williams \& Wilkins.

Kawamoto, I., Oka, T. \& Nara, T. (1981). Cell wall composition of Micromonospora olivasterospora, Micromonospora sagamiensis, and related organisms. J Bacteriol 146, 527-534.

Kroppenstedt, R. M. (1985). Fatty acid and menaquinone analysis of actinomycetes and related organisms. In Chemical Methods in Bacterial Systematics (Society for Applied Bacteriology Technical Series vol. 20), pp. 173-199. Edited by M. Goodfellow \& D. E. Minnikin. New York: Academic Press.

Kroppenstedt, R. M., Mayilraj, S., Wink, J. M., Kallow, W., Schumann, P., Secondini, C. \& Stackebrandt, E. (2005). Eight new species of the genus Micromonospora, Micromonospora citrea sp. nov., Micromonospora echinaurantiaca sp. nov., Micromonospora echinofusca sp. nov., Micromonospora fulviviridis sp. nov., Micromonospora inyonensis sp. nov., Micromonospora peucetia sp. nov., Micromonospora sagamiensis sp. nov., and Micromonospora viridifaciens sp. nov. Syst Appl Microbiol 28, 328-339.

Kudo, T., Itoh, T., Miyadoh, S., Shomura, T. \& Seino, A. (1993). Herbidospora gen. nov., a new genus of the family Streptosporangiaceae Goodfellow et al. 1990. Int J Syst Bacteriol 43, 319-328.

Kumar, S., Tamura, K. \& Nei, M. (2004). MEGA3: integrated software for molecular evolutionary genetics analysis and sequence alignment. Brief Bioinform 5, 150-163.

Lechevalier, M. P. \& Lechevalier, H. A. (1970). Chemical composition as a criterion in the classification of aerobic actinomycetes. Int J Syst Bacteriol 20, 435-443. 
Lechevalier, M. P., De Bievre, C. \& Lechevalier, H. (1977). Chemotaxonomy of aerobic actinomycetes: phospholipid composition. Biochem Syst Ecol 5, 249-260.

Mikami, H. \& Ishida, Y. (1983). Post-column fluorometric detection of reducing sugars in high-performance liquid chromatography using arginine. Bunseki Kagaku 32, E207-E210.

Minnikin, D. E., O’Donnell, A. G., Goodfellow, M., Alderson, G., Athalye, M., Schaal, A. \& Parlett, J. H. (1984). An integrated procedure for the extraction of bacterial isoprenoid quinones and polar lipids. J Microbiol Methods 2, 233-241.

Nakajima, Y., Kitpreechavanich, V., Suzuki, K. \& Kudo, T. (1999). Microbispora corallina sp. nov., a new species of the genus Microbispora isolated from Thai soil. Int J Syst Bacteriol 49, 1761-1767.

Orskov, J. (1923). Investigations into the Morphology of the Ray Fungi. Copenhagen: Levin and Munksgaard.

Saitou, N. \& Nei, M. (1987). The neighbor-joining method: a new method for reconstructing phylogenetic trees. Mol Biol Evol 4, 406-425.

Sasser, M. (1990). Identification of bacteria by gas chromatography of cellular fatty acids. MIDI Technical Note 101. Newark, DE: MIDI.

Shirling, E. B. \& Gottlieb, D. (1966). Methods for characterization of Streptomyces species. Int J Syst Bacteriol 16, 313-340.

Staneck, J. L. \& Roberts, G. D. (1974). Simplified approach to identification of aerobic actinomycetes by thin-layer chromatography. Appl Microbiol 28, 226-231.

Stevenson, I. L. (1967). Utilization of aromatic hydrocarbons by Arthrobacter spp. Can J Microbiol 13, 205-211.

Suzuki, K. \& Komagata, K. (1983). Taxonomic significance of cellular fatty acid composition in some coryneform bacteria. Int $J$ Syst Bacteriol 33, 188-200.

Tamaoka, J. (1994). Determination of DNA base composition. In Chemical Methods in Prokaryotic Systematics, pp. 463-470. Edited by M. Goodfellow \& A. G. O’Donnell. Chichester: Wiley.

Tamaoka, J. \& Komagata, K. (1984). Determination of DNA base composition by reversed-phase high-performance liquid chromatography. FEMS Microbiol Lett 25, 125-128.

Thawai, C., Tanasupawat, S., Itoh, T., Suwanborirux, K. \& Kudo, T. (2004). Micromonospora aurationigra sp. nov., isolated from a peat swamp forest in Thailand. Actinomycetologica 18, 8-14.
Thawai, C., Tanasupawat, S., Itoh, T., Suwanborirux, K. \& Kudo, T. (2005a). Micromonospora eburnea sp. nov., isolated from a Thai peat swamp forest. Int J Syst Evol Microbiol 55, 417-422.

Thawai, C., Tanasupawat, S., Itoh, T., Suwanborirux, K. \& Kudo, T. (2005b). Micromonospora siamensis sp. nov., isolated from Thai peat swamp forest. J Gen Appl Microbiol 51, 229-234.

Thawai, C., Tanasupawat, S., Suwanborirux, K., Itoh, T. \& Kudo, T. (2008). Micromonospora narathiwatensis sp. nov., from Thai peat swamp forest soils. J Gen Appl Microbiol 53, 287-293.

Thompson, J. D., Gibson, T. J., Plewniak, F., Jeanmougin, F. \& Higgins, D. G. (1997). CLUSTAL_X windows interface: flexible strategies for multiple sequence alignment aided by quality analysis tools. Nucleic Acids Res 25, 4876-4882.

Trujillo, M. E., Fernândez-Molinero, C., Velâzquez, E., Kroppenstedt, R. M., Schumann, P., Mateos, P. F. \& Martínez-Molina, E. (2005). Micromonospora mirobrigensis sp. nov. Int J Syst Evol Microbiol 55, 877-880.

Trujillo, M. E., Kroppenstedt, R. M., Schumann, P., Carro, L. \& Martínez-Molina, E. (2006). Micromonospora coriariae sp. nov., isolated from root nodules of Coriaria myrtifolia. Int J Syst Evol Microbiol 56, 2381-2385.

Trujillo, M. E., Kroppenstedt, R. M., Fernândez-Molinero, C., Schumann, P. \& Martínez-Molina, E. (2007). Micromonospora lupini sp. nov. and Micromonospora saelicesensis sp. nov., isolated from root nodules of Lupinus angustifolius. Int J Syst Evol Microbiol 57, 2799 2804.

Uchida, K. \& Aida, K. (1984). An improved method for the glycolate test for simple identification of the acyl type of bacterial cell walls. J Gen Appl Microbiol 30, 131-134.

Wayne, L. G., Brenner, D. J., Colwell, R. R., Grimont, P. A. D., Kandler, O., Krichevsky, M. I., Moore, L. H., Moore, W. E. C., Murray, R. G. E. \& other authors (1987). International Committee on Systematic Bacteriology. Report of the ad hoc committee on the reconciliation of approaches to bacterial systematics. Int $J$ Syst Bacteriol 37, 463-464.

Williams, S. T. \& Cross, T. (1971)..Actinomycetes. In Methods in Microbiology, vol. 4, pp. 295-334. Edited by C. Booth. London: Academic Press 